\title{
The Covid-19 Global Pandemic: A Natural Experiment in the Making
}

\author{
David M. Mutch ${ }^{\mathrm{a}}$

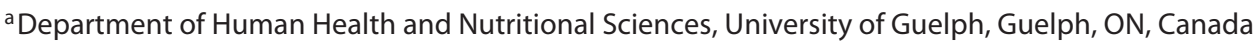

As news began to emerge from China in late 2019 of a new infectious respiratory disease, nobody realized that we were about to be enrolled into a global natural experiment. To paraphrase Craig et al. [1], a natural experiment describes an event or intervention not under the control of a researcher, where individuals in a population can be divided into exposed and unexposed groups. Unlike clinical trials and classic research studies, the intervention associated with a natural experiment is not constrained by ethics, public perception, or granting agencies. In fact, these natural experiments happen whether people want them to or not! This is exemplified by the Dutch Hunger Winter study, which relates the severe food rationing experienced in the Western part of The Netherlands during the winter of 1944-1945 with the programming of adult disease [2]. While the novel severe acute respiratory syndrome coronavirus 2 (SARS-CoV-2), more commonly known as COVID-19, has been devastating for people worldwide, the timeline of events spanning from closures and restrictions to phased reopenings is well documented. And when antibody testing becomes more widespread, it will be clearer who has, and who has not, been infected. With this information in hand, scientists will be able to advance our understanding of the modifiable and nonmodifiable risk factors underlying the severity of SARSCoV-2 infections as well as study the long-term health consequences associated with the significant life changes caused by the pandemic. The likely outcomes of this research will be far reaching and hopefully lead to new public health directives and fewer disparities in healthcare be- tween people. But, in the short-term, research that elucidates how the virus spreads, how it infects a person, and what factors can modify the severity of infection will all aid in the development of effective vaccines.

At the time of writing, over half a million people had succumbed to this virus and more than 12 million people had been infected worldwide. Jobs have been lost, businesses have gone bankrupt, and global economies have been battered, leaving very few people untouched by this pandemic. Throughout all of this, researchers worldwide are working together to advance our understanding of SARS-CoV-2 at an unprecedented speed. Genomic sequencing of viral samples isolated from infected individuals have allowed researchers to better understand not only its origins but also how SARS-CoV-2 is spreading around the world, which has helped public health agencies and governments to make informed decisions to curb the spread of this virus. Due to the rapid rate of mutation in RNA viruses such as SARS-CoV-2, viral genome sequencing will help to determine the origin of these outbreaks and their subsequent spread within a country [3]. Indeed, sequencing viral samples collected from patients in New York City during the early stages of the outbreak suggest that that majority of these cases were related to viral samples isolated from cases in Europe [4]. Even after strict travel restrictions were implemented, the virus spread rapidly across the USA and phylogenetic analyses have proved useful to clarify the importance of domestic transmission [5]. Moreover, recent bioinformatic analyses of complete viral genomes suggest increasing diversi- karger@karger.com www.karger.com/lfg Karger"
(C) 2020 The Author(s) Published by S. Karger AG, Basel Karge Open access This article is licensed under the Creative Commons AttributionNonCommercial-NoDerivatives 4.0 International License (CC BYNC-ND) (http://www.karger.com/Services/OpenAccessLicense) Usage and distribution for commercial purposes as well as any distribution of modified material requires written permission.
David M. Mutch

Department of Human Health and Nutritional Sciences University of Guelph, 50 Stone Road East Guelph, ON N1G 2W1 (Canada) dmutch@uoguelph.ca 
fication of SARS-CoV-2 strains [6]. Together, genomic insights such as these will prove critical for the identification of future vaccine targets [7].

What is now becoming apparent is that various factors, both nonmodifiable and modifiable, exist that influence a person's risk of infection. The first genome-wide association study was recently reported from $\sim 2,000$ patients at 7 hospitals in Italy and Spain [8]. Compared with controls, 2 SNP (rs11385942 at locus 3p21.31 and rs657152 at locus $9 \mathrm{q} 34.2$ ) were found to be statistically significant in the 2 panels of patients. Interestingly, the association at $9 \mathrm{q} 34.2$ aligned with the $\mathrm{ABO}$ blood group locus, where individuals in blood group A showed a higher risk of infection and blood group $\mathrm{O}$ a protective effect compared with other blood groups. This is an intriguing finding that requires independent verification in forthcoming studies but suggests a possible role for blood type in infection susceptibility. Interestingly, SARS-CoV-2 pathogenesis involves the angiotensin converting enzyme-2 (ACE2) receptor. ACE2 gene expression is altered by various dietary components, such as resveratrol (increased gene and protein expression) and a high fat intake (decreased mRNA expression); thus, a potential nutrigenomic interaction may modify an individual's SARS-CoV-2 infection severity [9]. Furthermore, a study in patients with lupus showed that the ACE2 gene is under epigenetic control, where hypomethylation was associated with increased ACE2 gene expression [10]. Thus, it is plausible that lifestyle factors that regulate the epigenome may also alter a person's risk of infection. Collectively, investigations like this will clarify whether an underlying (epi-)genetic basis exists that can help to predict the risk of SARS-CoV-2 infection and whether this risk can be modified by diet.

Emerging research suggests that various lifestyle factors are associated with the severity of SARS-CoV-2 infection. For example, a study from the UK suggested that physical inactivity, smoking, and obesity $(\mathrm{BMI} \geq 30)$ are all associated with COVID-19 hospitalizations [11]. Similarly, smoking and a BMI $\geq 30$, among other factors, were also found to predict a negative clinical outcome in hospitalized patients from Wuhan, China [12]. What is quickly becoming apparent from studies around the globe is that obesity is an important risk factor for COVID-19 infections [13]. This is of concern given the worldwide prevalence of obesity, particularly in younger populations in Western countries. While many countries noted a high mortality rate in older populations $(>65$ years of age) compared to younger individuals, the USA observed that a significant number of patients admitted into hospitals were young individuals with obesity [14,
15]. Further, it appears that young patients with morbid obesity may experience a greater risk of mortality [16]. A high BMI was also found to significantly increase the risk of hospital admission and severe infection in the UK [11], France [17, 18], and Mexico [19]. Interestingly, the ACE2 receptor is highly expressed in adipose tissue; therefore, the increased number of ACE2-expressing cells in individuals with obesity provides a potential mechanism of action that warrants investigation [20]. Together, these findings suggest that unhealthy lifestyles, particularly those that promote obesity, appear to increase the severity of SARS-CoV-2 infection.

While unhealthy lifestyle habits established prior to the pandemic appear to influence a person's risk for severe infection, the strict restrictions imposed by governments worldwide in response to the pandemic have forced many people to drastically change their diet, physical activity, and sleep habits. These changes will undoubtedly have consequences on the prevalence and severity of chronic and mental diseases as we move forward. For example, negative changes in physical activity, sleep, alcohol intake, and smoking since the onset of COVID-19 were all associated with higher depression, anxiety, and stress in Australian adults [21]. In contrast, a report from Italy suggested a reduction in smoking habits and an increase in sleep during the strict lockdown period [22]. These 2 studies highlight the different responses seen in countries during the pandemic, which will permit interesting comparative analyses to be conducted in the future. Along these lines, countries (as well as different regions within a country) took different approaches regarding school closures, with some regions closing for several weeks and others closing for much longer. These closures meant that children lost their face-to-face social interactions for varying amounts of time, and many turned to online gaming for socialization. However, prolonged periods of technology during social isolation may increase the risk of establishing unhealthy lifestyle patterns (e.g., perturbed sleep habits) in young children that could have long-lasting consequences [23]. It is expected that many more studies like these will appear in the coming months and years, but the evidence already available indicates that many people's lifestyle habits have changed during the pandemic. This is notable given that evidence from past natural experiments has shown that major changes in lifestyle can promote epigenetic modifications that alter adult disease risk, in particular when these changes are experienced in utero and in early life [24]. Thus, it will be important to follow babies born at different points during the pandemic, as well as young children, to determine 
whether COVID-19-induced lifestyle changes in parents have any long-lasting ramifications on offspring as they age. Furthermore, based on past evidence that other coronaviruses can modify the host epigenome [25], it will be intriguing to investigate whether SARS-CoV-2 can promote epigenetic modifications directly that may influence adult disease risk.

Our knowledge surrounding SARS-CoV-2 continues to evolve on an almost daily basis. Ongoing research endeavors will continue to advance our understanding regarding the susceptibility to infection and generate invaluable knowledge for vaccine development. Further, the varying response to the pandemic seen both within and between countries will provide unique opportunities for comparative analyses that will help to clarify which lifestyle factors increase the risk of infection, as well as how pandemic-induced changes in lifestyle habits will affect future disease risks.

\section{Conflict of Interest Statement}

D.M.M. is editor-in-chief of Lifestyle Genomics. The views and opinions presented in this Editorial are his own.

\section{Funding Sources}

None to declare.

\section{References}

1 Craig P, Katikireddi SV, Leyland A, Popham F. Natural Experiments: An Overview of Methods, Approaches, and Contributions to Public Health Intervention Research. Annu Rev Public Health. 2017 Mar;38(1):39-56

2 Schulz LC. The Dutch Hunger Winter and the developmental origins of health and disease. Proc Natl Acad Sci USA. 2010 Sep;107(39): 16757-8.

3 Zhang YZ, Holmes EC. A Genomic Perspective on the Origin and Emergence of SARSCoV-2. Cell. 2020 Apr;181(2):223-7.

4 Maurano MT, Ramaswami S, Westby G, Zappile P, Dimartino D, Shen G, et al. Sequencing identifies multiple, early introductions of SARS$\mathrm{CoV} 2$ to New York City Region. medRxiv: the preprint server for health sciences. 2020. doi: https://doi.org/10.1101/2020.04.15.20064931.

5 Fauver JR, Petrone ME, Hodcroft EB, Shioda K, Ehrlich HY, Watts AG, et al. Coast-toCoast Spread of SARS-CoV-2 during the Early Epidemic in the United States. Cell. 2020 May;181(5):990-996.e5.

6 Castells M, Lopez-Tort F, Colina R, Cristina J. Evidence of Increasing Diversification of Emerging SARS-CoV-2 Strains. J Med Virol. 2020 May;jmv.26018.

7 Kames J, Holcomb DD, Kimchi O, DiCuccio M, Hamasaki-Katagiri N, Wang T, et al. Sequence analysis of SARS-CoV-2 genome reveals features important for vaccine design. bioRxiv : the preprint server for biology. 2020. https://doi.org/10.1101/2020.03.30.016832.

8 Ellinghaus D, Degenhardt F, Bujanda L, Buti M, Albillos A, Invernizzi P, et al.; Severe Covid-19 GWAS Group. Genomewide Association Study of Severe Covid-19 with Respiratory Failure. N Engl J Med. 2020 Jun; NEJMoa2020283.

9 Horne JR, Vohl MC. Biological plausibility for interactions between dietary fat, resveratrol, ACE2, and SARS-CoV illness severity. Am J Physiol Endocrinol Metab. 2020 May; 318(5):E830-3.
10 Sawalha AH, Zhao M, Coit P, Lu Q. Epigenetic dysregulation of ACE2 and interferonregulated genes might suggest increased COVID-19 susceptibility and severity in lupus patients. Clin Immunol. 2020 Jun;215: 108410.

11 Hamer M, Kivimäki M, Gale CR, Batty GD. Lifestyle risk factors, inflammatory mechanisms, and COVID-19 hospitalization: a community-based cohort study of 387,109 adults in UK. Brain Behav Immun. 2020 Jul; 87:184-7.

12 Hu L, Chen S, Fu Y, Gao Z, Long H, Wang JM, et al. Risk Factors Associated with Clinical Outcomes in 323 COVID-19 Hospitalized Patients in Wuhan, China. Clin Infect Dis. 2020 May;ciaa539.

13 Tamara A, Tahapary DL. Obesity as a predictor for a poor prognosis of COVID-19: A systematic review. Diabetes Metab Syndr. 2020 Jul - Aug;14(4):655-9.

14 Kass DA, Duggal P, Cingolani O. Obesity could shift severe COVID-19 disease to younger ages. Lancet. 2020 May;395(10236): $1544-5$.

15 Palaiodimos L, Kokkinidis DG, Li W, Karamanis D, Ognibene J, Arora S, et al. Severe obesity, increasing age and male sex are independently associated with worse in-hospital outcomes, and higher in-hospital mortality, in a cohort of patients with COVID-19 in the Bronx, New York. Metabolism. 2020 Jul;108: 154262.

16 Klang E, Kassim G, Soffer S, Freeman R, Levin MA, Reich DL. Morbid obesity as an independent risk factor for COVID-19 mortality in hospitalized patients younger than 50 . Obesity (Silver Spring). 2020. doi: 10.1002/ oby.22913.

17 Caussy C, Pattou F, Wallet F, Simon C, Chalopin S, Telliam C, et al.; COVID Outcomes HCL Consortium and Lille COVID-Obesity Study Group. Prevalence of obesity among adult inpatients with COVID-19 in France.
Lancet Diabetes Endocrinol. 2020 Jul;8(7): 562-4.

18 Simonnet A, Chetboun M, Poissy J, Raverdy V, Noulette J, Duhamel A, et al.; LICORN and the Lille COVID-19 and Obesity study group. High Prevalence of Obesity in Severe Acute Respiratory Syndrome Coronavirus-2 (SARSCoV-2) Requiring Invasive Mechanical Ventilation. Obesity (Silver Spring). 2020 Jul; 28(7):1195-9.

19 Bello-Chavolla OY, Bahena-López JP, Antonio-Villa NE, Vargas-Vázquez A, GonzálezDíaz A, Márquez-Salinas A, et al. Predicting mortality due to SARS-CoV-2: a mechanistic score relating obesity and diabetes to $\mathrm{CO}$ VID-19 outcomes in Mexico. J Clin Endocrinol Metab. 2020 Aug;105(8):dgaa346.

20 Kassir R. Risk of COVID-19 for patients with obesity. Obes Rev. 2020 Jun;21(6):e13034.

21 Stanton R, To QG, Khalesi S, Williams SL, Alley SJ, Thwaite TL, et al. Depression, Anxiety and Stress during COVID-19: Associations with Changes in Physical Activity, Sleep, Tobacco and Alcohol Use in Australian Adults. Int J Environ Res Public Health. 2020 Jun; 17(11):E4065.

22 Di Renzo L, Gualtieri P, Pivari F, Soldati L, Attinà A, Cinelli G, et al. Eating habits and lifestyle changes during COVID-19 lockdown: an Italian survey. J Transl Med. 2020 Jun;18(1):229.

23 King DL, Delfabbro PH, Billieux J, Potenza $\mathrm{MN}$. Problematic online gaming and the $\mathrm{CO}$ VID-19 pandemic. J Behav Addict. 2020 Apr. https://doi.org/10.1556/2006.2020.00016.

24 Dominguez-Salas P, Cox SE, Prentice AM, Hennig BJ, Moore SE. Maternal nutritional status, C(1) metabolism and offspring DNA methylation: a review of current evidence in human subjects. Proc Nutr Soc. 2012 Feb; 71(1):154-65.

25 Schäfer A, Baric RS. Epigenetic Landscape during Coronavirus Infection. Pathogens. 2017 Feb;6(1):E8.
The Covid-19 Global Pandemic: A Natural Experiment in the Making
Lifestyle Genomics 2020;13:135-137 DOI: $10.1159 / 000510217$ 